\title{
Molecular population genetics of the malaria vector Anopheles darlingi in Central and South America
}

\author{
L Mirabello ${ }^{1}$ and JE Conn ${ }^{1,2}$ \\ ${ }^{1}$ Department of Biomedical Sciences, Division of Immunology and Infectious Disease, University at Albany, State University of New \\ York, 1400 Washington Avenue, Albany, NY 12222, USA; ${ }^{2}$ Wadsworth Center, Griffin Laboratory, New York State Department of \\ Health, 5668 State Farm Road, Slingerlands, NY 12159, USA
}

\begin{abstract}
To analyze the genetic relatedness and phylogeographic structure of Anopheles darlingi from 19 localities throughout Central and South America, we used a minimum spanning network, diversity measures, differentiation, neutrality tests, and mismatch distribution with mitochondrial cytochrome oxidase subunit I (COI) sequences. All the Central American haplotypes were separated by seven mutational steps from the South American haplotypes and the $F_{\mathrm{ST}}$ distance-based neighbor-joining tree showed a primary division between Central and South America, evidence for a putative gene pool division. More ancestral and diverse haplotypes were found in Amazonian and southern Brazil populations,
\end{abstract}

suggesting that Central American populations may have originated in South America. The patterns of the mtDNA haplotype diversity and five of six tests for equilibrium implicate demographic expansion in the South American populations as the historical structure, but mismatch distribution depicts populations at mutation drift equilibrium (MDE). In South America, the departure from equilibrium was consistent with an expansion that occurred during the Pleistocene.

Heredity (2006) 96, 311-321. doi:10.1038/sj.hdy.6800805; published online 1 March 2006

Keywords: Anopheles darlingi; malaria vector; population genetics; mtDNA; range expansion

\section{Introduction}

Globally, there are approximately 273 million annual malaria cases, and greater than 2.1 billion people are at risk of malaria (WHO/TDR, 2004). There are an estimated 960000 cases of malaria reported in the Americas, and approximately $41 \%$ occur in Brazil $(99 \%$ in the Amazon region) (PAHO, 2002). One of the factors determining the degree of malaria endemicity in a susceptible geographic region is the species of mosquito vector present. Vector species and population differences within species influence biting times, feeding and resting sites, and anthropophily (Lounibos and Conn, 2000), and these behaviors determine human mosquito contact. The factors that affect the vector's capacity to transmit the plasmodium parasite vary with species and population, and include mosquito abundance, infection rate, anthropophily, and longevity (Foster and Walker, 2002).

In the Neotropics, relative abundances of important malaria vectors have changed temporally, such as Anopheles albitarsis in southeastern Brazil (Forattini et al, 1993), Anopheles marajoara in northern Amazonian Brazil (Conn et al, 2002; Lehr, 2003) and A. darlingi in western Amazonian Brazil (Soares Gil et al, 2003) and in the city of Belém (Póvoa et al, 2003). Anopheles albitarsis has emerged in southeastern Brazil possibly due to the development of irrigated land (Forattini et al, 1993). Anopheles darlingi's recent resurgence, in places such as

Correspondence: JE Conn, Wadsworth Center, Griffin Laboratory, New York State Department of Health, 5668 State Farm Rd, Slingerlands, NY 12159, USA. E-mail: jconn@wadsworth.org

Received 24 March 2005; accepted 15 November 2005; published online 1 March 2006
Iquitos, Peru has been linked to increased malaria cases (Aramburu Guarda et al, 1999; Schoeler et al, 2003). The resurgence of $A$. darling $i$ is proposed to be a result of human migration and land use changes, which often result in invasion of its primary breeding sites along warm lowland rivers and subsequent increased abundance (Charlwood, 1996; Conn et al, 1999). Such anthropogenic changes highlight important aspects of targeted malaria control: the possibility of altering locally important vectors, and complicated interactions with human populations (Conn et al, 2002; Póvoa et al, 2003).

Anopheles darlingi is the most important malaria vector in the Amazon Basin (Deane, 1947, 1988). In addition to high rates of infection, $A$. darlingi is also a good malaria vector owing to its anthropophilic (Charlwood and Alecrim, 1989) and endophagic (feeds indoors) behavior (Lourenço-de-Oliveira et al, 1989); although recently it is thought to have evolved to be more exophilic (rests outdoors) as a result of prolonged residual insecticide use in many regions (Charlwood, 1996; Soares Gil et al, 2003). Anopheles darlingi has an extensive distribution from southern Mexico to southern Brazil (Forattini, 1962). Although there are no documented barriers to gene flow for A. darlingi, rDNA data that detected a fixed insertion/deletion in samples from Belize, but not in those from South America (Manguin et al, 1999), are suggestive. Anopheles albimanus and A. pseudopunctipennis, with distributions similar to $A$. darlingi, are differentiated between Central and South America (De Merida et al, 1995, 1999; Manguin et al, 1995), possibly due to vicariance (Krzywinski and Besansky, 2003) or barriers to gene flow in Costa Rica and Panama (Molina-Cruz et al, 2004). 
Even though $A$. darling $i$ is considered a single species (reviewed in Manguin et al, 1999; Lounibos and Conn, 2000), it does exhibit heterogeneity in body size (Charlwood, 1996) and in some genetic markers such as polytene chromosomes (Kreutzer et al, 1972), mtDNA (Freitas-Sibajev et al, 1995; Conn et al, 1999) and rDNA ITS2 sequences (Malafronte et al, 1999). The observed heterogeneity can affect important behavioral determinants of vector efficiency, such as endophily (rests indoors) and possibly dispersal ability (range expansion) (Lounibos and Conn, 2000; Fairley et al, 2002). Within species differentiation can also affect the efficacy of control techniques; for example, variation in biting times can affect usefulness of personal protection measures (Zimmerman and Voorham, 1997).

Owing to their relationship to human populations, many anopheline mosquito species are likely to violate mutation drift equilibrium (MDE) assumptions (Donnelly et al, 2001). One result of this is inaccurate estimates of gene flow, which can confound potential choices of target populations for the introduction of refractory genes. Avise (2000) suggests that closely related species in the same geographic region should have similar demographic histories due to their phylogenetic relatedness. In the northeastern Amazon, Lehr (2003) demon- strated that $A$. marajoara, a close relative of $A$. darlingi (Sallum et al, 2000), has undergone a recent population expansion, and is therefore not at MDE.

In the present study, we analyze the population structure of $A$. darlingi from 19 localities throughout Central and South America, including Brazil, Peru, Belize, Colombia, French Guiana, and Guatemala. Using sequences of the mitochondrial cytochrome oxidase subunit I (COI) gene, we test the hypothesis that A. darlingi will have a similar demographic history to A. marajoara in the northeastern Amazon (Avise, 2000) and determine whether there is a division in the gene pool between Central and South America, as proposed by Krzywinski and Besansky (2003).

\section{Materials and methods}

\section{Mosquito collections}

Adult $A$. darlingi were collected outdoors between 19:00 and 21:00 h by human landing catches and identified morphologically using the key of Deane et al (1946). The human landing catch protocol was reviewed and approved by the Institutional Review Board of the New York State Department of Health and by the Biosafety

Table 1 Anopheles darlingi collection localities

\begin{tabular}{|c|c|c|c|c|}
\hline Site no. & Locality (abbreviation) & Latitude/longitude coordinates & $\mathrm{n}$ & Collector \\
\hline & $\begin{array}{l}\text { Brazil } \\
\text { Amapá State }\end{array}$ & & & \\
\hline 1 & Tartarugalzinho (TAR) & $1^{\circ} 19^{\prime} \mathrm{N}, 50^{\circ} 57^{\prime} \mathrm{W}$ & 5 & MM Póvoa and JE Conn \\
\hline 2 & Lagoa dos Indios (LI) & $0^{\circ} 2^{\prime} \mathrm{S}, 51^{\circ} 11^{\prime} \mathrm{W}$ & 4 & MM Póvoa and JE Conn \\
\hline 3 & Santo Antonio (ANT) & $0^{\circ} 5.452^{\prime} \mathrm{S}, 51^{\circ} 12.579^{\prime} \mathrm{W}$ & 6 & MM Póvoa and JE Conn \\
\hline & Pará State & & & \\
\hline 4 & Itaituba (ITB) & $4^{\circ} 15^{\prime} \mathrm{S}, 55^{\circ} 59^{\prime} \mathrm{W}$ & 4 & MM Póvoa and JE Conn \\
\hline 5 & Tailândia (TAI) & $2^{\circ} 57^{\prime} \mathrm{S}, 48^{\circ} 59^{\prime} \mathrm{W}$ & 5 & MM Póvoa and JE Conn \\
\hline 6 & Belém (BEL) & $1^{\circ} 25^{\prime} \mathrm{S}, 48^{\circ} 77^{\prime} \mathrm{W}$ & 6 & MM Póvoa and JE Conn \\
\hline 7 & Invasão Carlos Mariguela (ARA) & $1^{\circ} 37^{\prime} 526^{\prime \prime} \mathrm{S}, 48^{\circ} 36^{\prime} 925^{\prime \prime} \mathrm{W}$ & 5 & MM Póvoa and JE Conn \\
\hline 8 & Peixe-boi (PEB) & $1^{\circ} 11^{\prime} \mathrm{S}, 47^{\circ} 17^{\prime} \mathrm{W}$ & 5 & MM Póvoa and JE Conn \\
\hline 9 & Mojú (MOJ) & $1^{\circ} 52^{\prime} \mathrm{S}, 48^{\circ} 45^{\prime} \mathrm{W}$ & 5 & MM Póvoa and JE Conn \\
\hline 10 & Capanema (CAP) & $1^{\circ} 0-12^{\prime} \mathrm{S}, 47^{\circ} 11-18^{\prime} \mathrm{W}$ & 3 & RC Wilkerson \\
\hline & Roraima State & & & \\
\hline 11 & Boa Vista (BV) & $2^{\circ} 49^{\prime} \mathrm{N}, 60^{\circ} 40^{\prime} \mathrm{W}$ & 5 & MM Póvoa and JE Conn \\
\hline & Mato Grosso State & & & \\
\hline 12 & Peixoto de Azevedo (PEX) & $10^{\circ} 23^{\prime} \mathrm{S}, 54^{\circ} 54^{\prime} \mathrm{W}$ & 5 & RC Wilkerson \\
\hline & São Paulo State & & & \\
\hline 13 & Dourado (DOU) & $22^{\circ} 7^{\prime} \mathrm{S}, 48^{\circ} 18^{\prime} \mathrm{W}$ & 10 & RC Wilkerson \\
\hline & Peru & & & \\
\hline 14 & Iquitos (IQ) & $3^{\circ} 45^{\prime} \mathrm{S}, 73^{\circ} 14^{\prime} \mathrm{W}$ & 5 & RH Gilman \\
\hline & Belize & & & \\
\hline 15 & Golden Stream (GOL) & $16^{\circ} 19^{\prime} \mathrm{N}, 88^{\circ} 47^{\prime} \mathrm{W}$ & 6 & JP Grieco \\
\hline 16 & Cayo (CAY) & $17^{\circ} 7-18^{\prime} \mathrm{N}, 88^{\circ} 34-40^{\prime} \mathrm{W}$ & 6 & JP Grieco \\
\hline & Colombia & & & \\
\hline 17 & Nechi (NEC) & $8^{\circ} 5^{\prime} \mathrm{N}, 74^{\circ} 46^{\prime} \mathrm{W}$ & 5 & R González \\
\hline & French Guiana & & & \\
\hline 18 & Trou-Poisson (TRP) & $5^{\circ} 26^{\prime} \mathrm{N}, 53^{\circ} 5^{\prime} \mathrm{W}$ & 9 & S Manguin \\
\hline 19 & $\begin{array}{l}\text { Guatemala } \\
\text { Ixana (IXA) }\end{array}$ & $15^{\circ} 47^{\prime} \mathrm{N}, 91^{\circ} 5^{\prime} \mathrm{W}$ & 9 & N Padilla \\
\hline
\end{tabular}

$n$ is the number of mosquitoes sequenced from that locality. 
Committee of the Instituto Evandro Chages, Belém, Brazil. Table 1 depicts the 19 localities, longitude and latitude of each site, and number of mosquitoes sequenced. All mosquitoes were maintained in 95\% ethanol at $-80^{\circ} \mathrm{C}$ until use. DNA from each specimen used herein has been retained as a frozen voucher at $-80^{\circ} \mathrm{C}$ in the Conn Laboratory.

\section{DNA extraction and sequencing}

DNA was isolated from the head, thorax, or legs using the DNeasy tissue kit, following standard DNeasy Tissue Handbook protocol for isolation of total DNA from animal tissues (Qiagen, CA, USA). A $1300 \mathrm{bp}$ fragment of the COI gene was amplified using the forward primer UEA3 and the reverse primer UEA10 (Lunt et al, 1996). Each individual PCR reaction was performed using a Ready-To-Go-PCR bead (Amersham Pharmacia/Biotech, NJ, USA) and run on a PTC-200 thermal cycler (BioRad, Inc.). The PCR products were cleaned with CentriSpin 40 columns (Princeton Separations, NJ, USA), and sent to the Wadsworth Center Molecular Genetics Core for sequencing. The forward and reverse sequences were aligned using Sequencher 3.0 (Gene Codes Corp, MI, USA), grouped together by site and trimmed in PAUP, version 4.0 (Swofford, 2003), creating a $978 \mathrm{bp}$ fragment of the COI gene. Unique haplotypes were determined using MacClade, version 3.0 (Maddison and Maddison, 1997); identical sequences were considered to be a single haplotype.

\section{Phylogenetic relatedness}

The number of mutational steps necessary to link any two haplotypes with 95\% confidence level was determined in ParsProb 1.1 (Posada et al, 2000). A minimum spanning network of the $A$. darlingi haplotypes was created using TCS 1.12 (Clement et al, 2000). Phylogenetic relationships among the haplotypes were estimated with PAUP using maximum likelihood and maximum parsimony (Swofford, 2003), and with $\mathrm{Mr}$ Bayes using a Bayesian approach (Rannala and Yang, 1996; Mau and Newton, 1997; Mau et al, 1999). Anopheles albimanus was used as an outgroup (Sallum et al, 2000). Pairwise population estimates of $F_{\mathrm{ST}}$ were computed using Arlequin 2.01 (Schneider et al, 2000), and the $F_{\text {ST }}$ values were used as distance measures to create a neighbor-joining (NJ) tree using Mega V2.1 (Kumar et al, 2001).

\section{Historical demography}

The haplotype and nucleotide diversities were computed in Arlequin 2.01 (Schneider et al, 2000). Nei's GST was calculated to estimate the population differentiation based on differences in allele frequencies; Nei's $N_{\mathrm{M}}$ was used to estimate gene flow based on $G_{\mathrm{ST}}$ (Nei, 1973). The tests of Tajima (1989) and Fu and Li (1993) were used to test the hypothesis that all mutations are selectively neutral (Kimura, 1983). Tajima's $D_{\mathrm{T}}$ (1989) is based on the differences between the number of segregating sites and the average number of nucleotide differences. The $D$ and $F$ tests, proposed by $\mathrm{Fu}$ and $\mathrm{Li}$ (1993), are based on molecular polymorphism data. Fu's $F_{S}$ test (1997) and Strobeck's S statistic (1987) assess the haplotype structure based on the haplotype frequency distribution, and were used as additional tests of neutrality. These analyses were calculated using DnaSP, version 3 (Rozas and Rozas, 1999). The mismatch distribution (a frequency distribution of the observed number of pairwise sequence differences) was performed to distinguish between a smooth unimodal distribution and a multimodal, or ragged, distribution (Slatkin and Hudson, 1991; Rogers and Harpending, 1992; Rogers, 1995). The raggedness $(r)$ statistic was calculated to quantify the smoothness of the mismatch distribution (Harpending et al, 1993). The Mantel analysis was used to test the null hypothesis of the independence of the geographic and genetic distance by a pairwise matrix of geographical and genetic distances (estimated by $F_{\mathrm{ST}}$ ). The mismatch distribution and Mantel test (Mantel, 1967) were calculated in Arlequin 2.01 (Schneider et al, 2000), and the raggedness test in DnaSP, version 3 (Rozas and Rozas, 1999). Significance of the Mantel test was determined by a permutation test of $n=1000$.

\section{Results}

\section{Genetic variation}

Of the 36 unique haplotypes detected, seven were shared $(\mathrm{A}, \mathrm{B}, \mathrm{C}, \mathrm{J}, \mathrm{T}, \mathrm{W}$, and $\mathrm{X})$; the remainder were unique to a single geographic location (Figure 1). All the sequences were A-T rich (combined frequency of $72.05 \%$ ), which is expected within Insecta. Sixty-nine transitions and seven transversions were identified, and there were four nonsynonymous mutations. A mutation at position 45 resulted in a methionine present in haplotype $\mathrm{V}(A$. darlingi in ARA) in place of a valine in all other haplotypes. Another southern Amazonian mutation resulted in an isoleucine in place of a valine in haplotype W (A. darlingi in ARA, BEL, and CAP). A nonsilent mutation at position 193 produced a threonine in haplotype $\mathrm{N}$ ( $A$. darlingi in NEC) where an alanine is present in all other haplotypes; and a mutation in haplotype $\mathrm{Q}(A$. darlingi in IQ) resulted in an alanine in place of a threonine. There were no nonfunctional genes (ie, pseudogenes) as shown by the absence of stop codons, the prevalence of synonymous substitutions, low pairwise divergence and clear electrophorograms. The two most common haplotypes were $\mathrm{T}(n=17)$ in Belize and Guatemala, and B $(n=15)$ in northeastern Amazonian Brazil (Table 2). Localities south of the Amazon region in Brazil have the highest haplotype diversities (ITB, MOJ, PEX, and DOU), and localities just northeast and southeast of the Amazon have the most shared haplotypes within the populations (TAR, LI, ANT, TRP. TAI, BEL, ARA, PEB, and CAP) (Figure 1; Table 2). Populations in close geographic proximity have the greatest quantity of shared haplotypes, and populations that are farther apart do not share haplotypes. Interestingly, localities directly northeast (TAR, LI, ANT, and TRP) and southeast of the Amazon (TAI, BEL, ARA, PEB, MOJ, and CAP) do not share haplotypes, and localities northeast of the Amazon (TAR, LI, ANT, and TRP) only have two unique haplotypes (Table 2). Haplotypes in Peru and Colombia are not shared among any other population, which could be due to their geographic separation from other localities sampled and (or) potential geographic or climatic barriers. In general, these data would seem to support the isolation by distance model (Wright, 1951). Belize and Guatemala had 


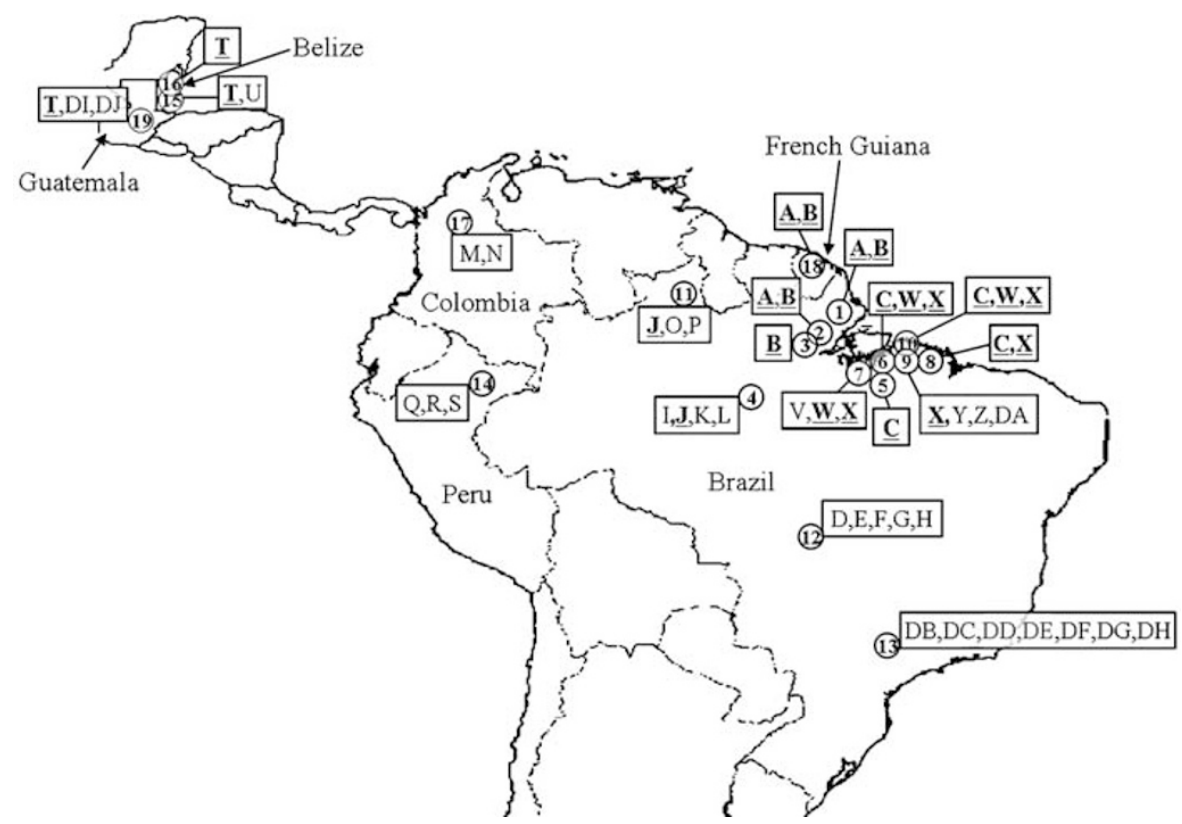

Figure 1 Geographic distribution of unique haplotypes in Central and South America. The letters correspond to the haplotype(s) observed for each locality. The circled numbers correspond to the locality in Table 1, positioned on the map according to longitude and latitude of the site. Underlined bold letters depict shared haplotypes, and plain letters depict unique haplotypes.

Table 2 Summary of haplotypes and diversity measures

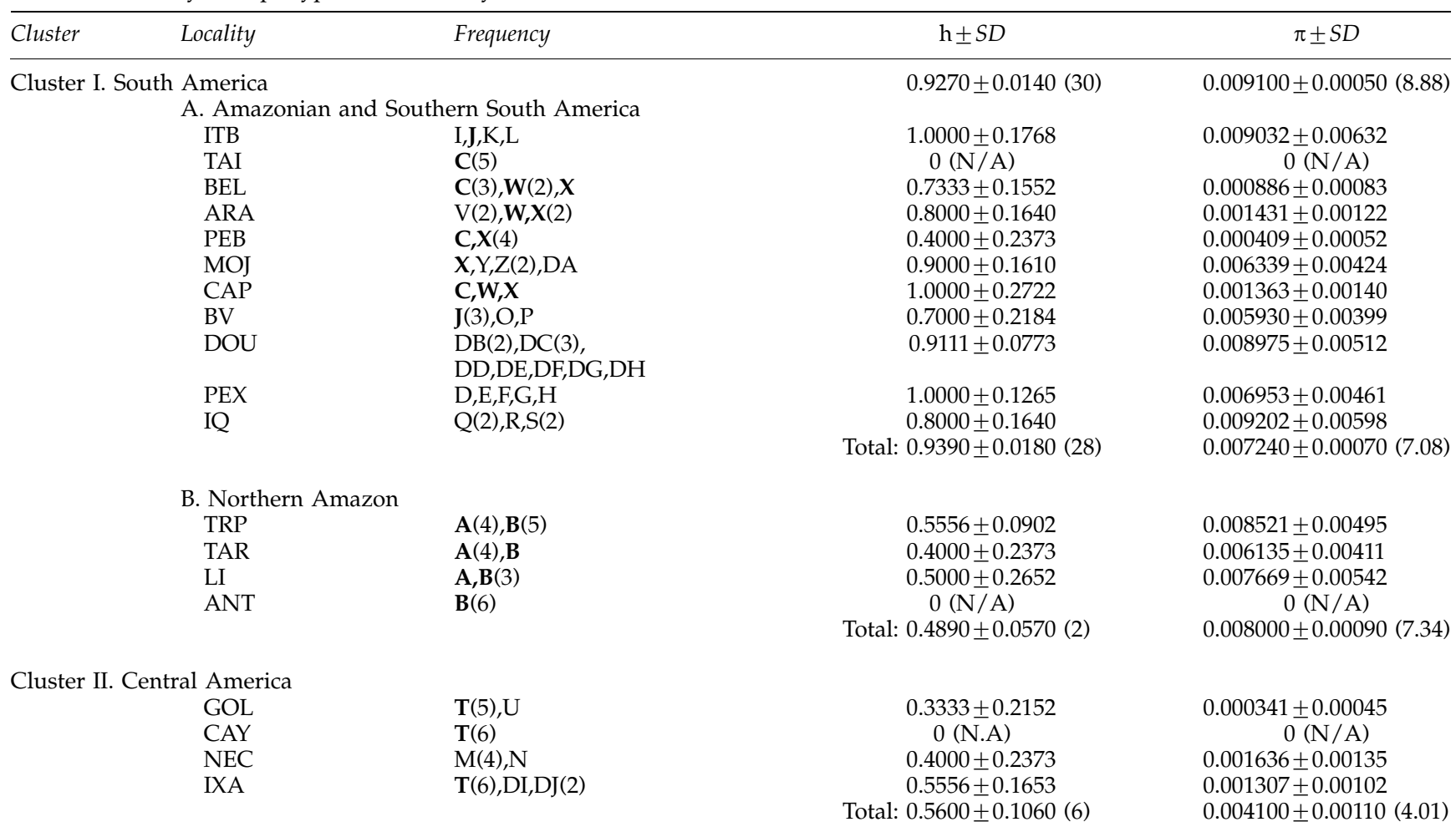

Frequency = haplotype frequency; the number in parentheses indicates the frequency of the haplotype at that site; bold letters are shared haplotypes and plain letters are unique haplotypes in that population. $h=$ haplotype diversity \pm standard deviation (the total number of haplotypes in that cluster or subcluster); $\pi=$ nucleotide diversity \pm standard deviation (average number of nucleotide differences in that cluster or subcluster).

low diversity with only four haplotypes identified from 21 mosquitoes analyzed. Haplotype $X$ is shared among the greatest number of populations in Brazil, followed by
B and C (Table 2). Sequences for $A$. darlingi and $A$. albimanus used in this study have been deposited in GenBank, accession numbers DQ298209 to DQ298244. 


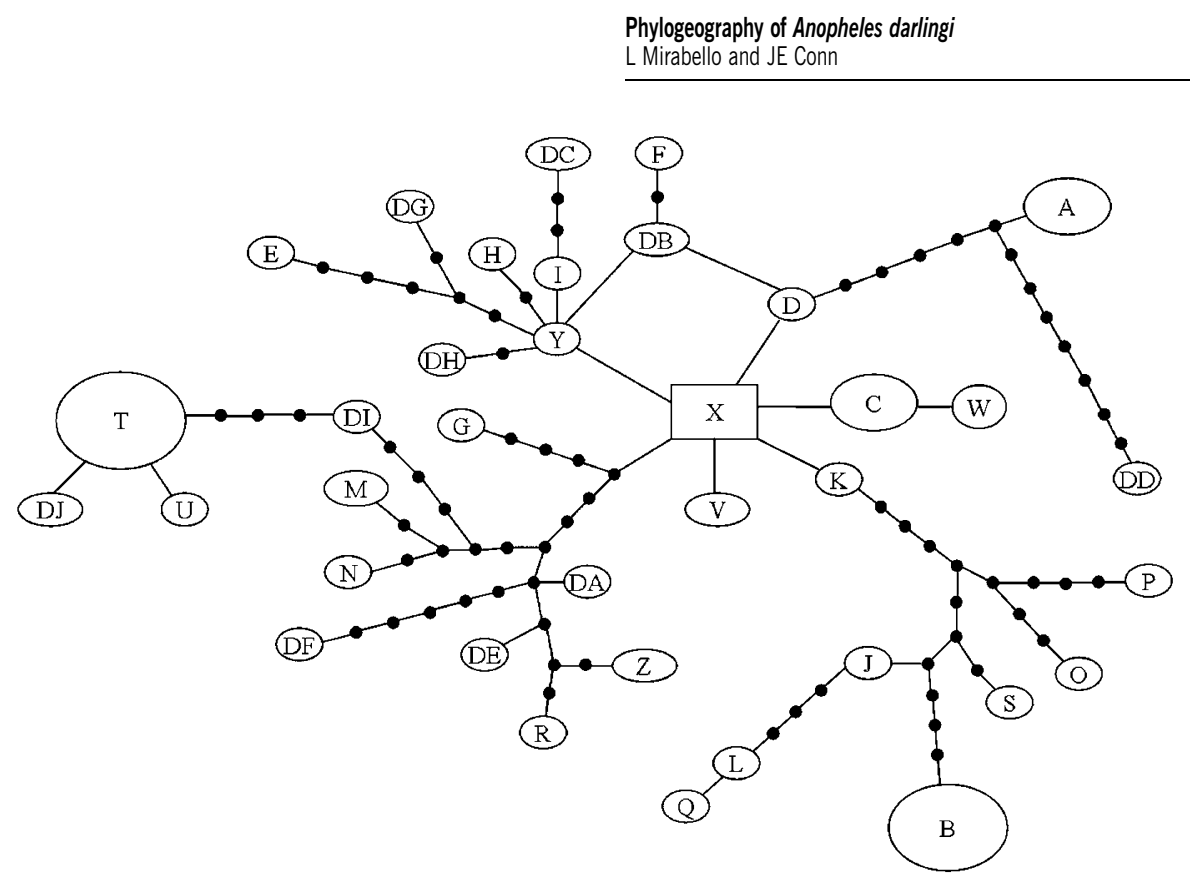

Figure 2 Parsimony network of the 36 haplotypes. The letters correspond to the haplotypes observed for the 19 localities in Table 2 . The solid circles represent a single mutational event.

\section{Phylogeographic relatedness}

The minimum spanning network illustrates the mutational relationship of the A. darlingi haplotypes (Figure 2). All haplotypes differed by less than 13 mutational steps, so they could be connected parsimoniously. The Central American haplotypes are separated by seven mutational steps from the Colombian haplotypes (M and N), which are separated by an additional seven mutational steps from a Brazilian haplotype, DA. Many southern Amazonian Brazil haplotypes (X, C, W, V, Y, K, I) differed by only one or two mutational steps, suggestive of a demographic expansion (Slatkin and Hudson, 1991; Fu, 1997). Haplotype $X$ was the most common interior haplotype, so is most likely the oldest haplotype (Castelloe and Templeton, 1994). The majority of haplotypes were tip alleles, and are considered as more recently derived and geographically restricted (Crandall and Templeton, 1993; Castelloe and Templeton, 1994).

The phylogenetic relationship among the haplotypes using the maximum-likelihood, maximum-parsimony, and Bayesian analyses were all very poorly resolved and not informative because the sequence variation contains insufficient phylogenetic signal (data not shown).

The $F_{\mathrm{ST}}$ pairwise estimates of differentiation ranged from 0 to 1 , and were used to create the NJ tree. Two primary clusters were found: (I) South America, and, (II) Central America plus NW Colombia (Figure 3). There appears to be a secondary division within cluster I between the southern Amazon and southern South America (IA) and the Northern Amazon (IB). The pairwise comparisons of $F_{\mathrm{ST}}$ within clusters I and II were 52.5 and $55 \%$ significant, respectively, and the $F_{\mathrm{ST}}$ comparisons between clusters were $100 \%$ significant $\left(F_{\mathrm{ST}}\right.$ values shown in Table 3) (Donnelly et al, 2004). Additional support for the primary division is found from samples of the conserved nuclear white gene that were cloned and sequenced for over 200 samples of $A$. darlingi from most of the same localities as in the current study (Mirabello and Conn, unpublished).

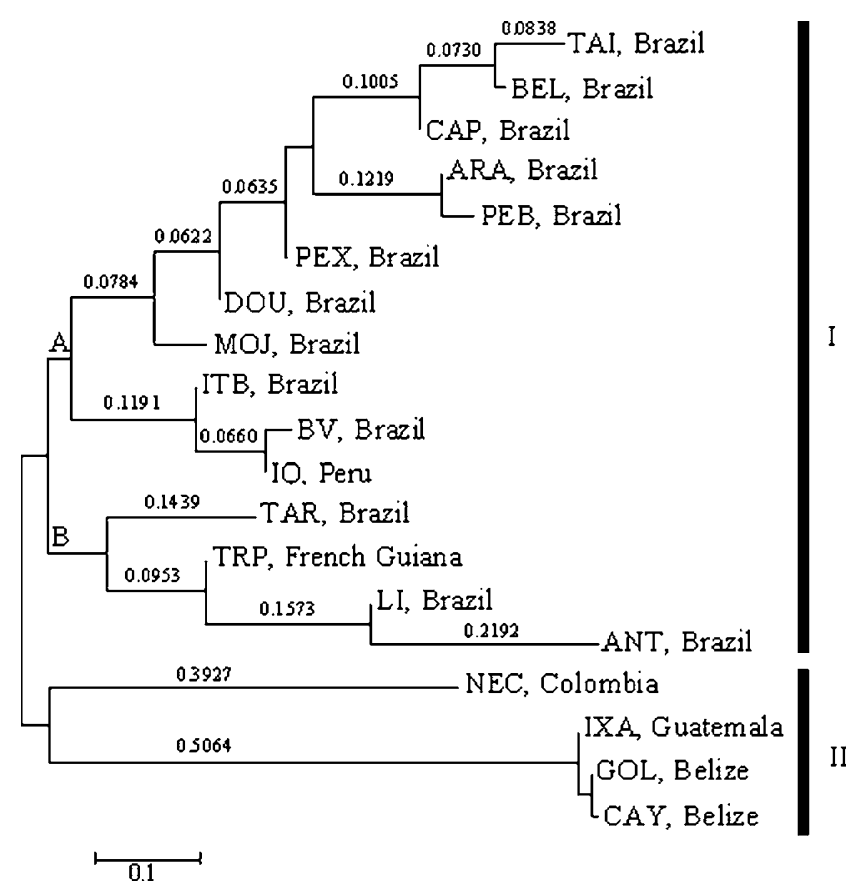

Figure $3 F_{\mathrm{ST}}$ distance-based neighbor-joining tree for Anopheles darlingi from $C O I$ mtDNA sequences. The mean pairwise $F_{\mathrm{ST}}$ values are proportional to the branch lengths (see scale bar). The pairwise $F_{\mathrm{ST}}$ comparisons within each cluster were significant $(P<0.05)$ for $52.5 \%$ of cluster I, and 55\% of cluster II. The pairwise estimates of $F_{\text {ST }}$ were $100 \%$ significantly different $(P<0.05)$ when samples from the two clusters were compared.

\section{Historical demography}

Nucleotide and haplotype diversities were used as measures of genetic diversity of $A$. darlingi. Haplotypes $\mathrm{B}$ and $\mathrm{T}$ had the greatest haplotype frequency (Table 2). ITB, CAP, and PEX had the highest haplotype diversities. ANT, TAI, and CAY had no detectable diversity 
Table 4 Pairwise differentiation $\left(G_{\mathrm{ST}}\right.$, below the diagonal), and gene flow between population clusters $\left(N_{\mathrm{M}}\right.$, above diagonal)

\begin{tabular}{lccc}
\hline & \multicolumn{2}{c}{ I. South America } & $\begin{array}{c}\text { II. Central } \\
\text { America }\end{array}$ \\
\cline { 2 - 3 } & $\begin{array}{l}\text { A. Amazonian } \\
\text { SSA }\end{array}$ & $\begin{array}{c}\text { B. Northern } \\
\text { Amazon }\end{array}$ & \\
\hline I. South America & & & \\
$\quad$ A. Amazonian and SSA & $*$ & 1.68 & 1.89 \\
$\quad$ B. Northern Amazon & 0.1299 & $*$ & 0.55 \\
II. Central America & 0.1169 & 0.3109 & $*$
\end{tabular}

South America includes all of the localities in South America except $\mathrm{Nec}$ (Colombia). Amazonian and SSA (Southern South America) includes Tai, Bel, Ara, Peb, Moj, Cap, Dou, Pex, Itb, BV, IQ (Peru). Northern Amazon includes Tar, Li, Ant, Trp (French Guiana). Central America includes Ixa, Gol, Cay, Nec (Colombia).

measures because only a single haplotype was detected in each. Both of the diversity measures were high in ITB, DOU, and IQ. The NJ cluster with the greatest haplotype diversity was IA, and IB had the highest nucleotide diversity (also having the greatest average number of nucleotide differences). Cluster II had low haplotype and nucleotide diversity measures.

Nei's $G_{S T}$ and $N_{M}$ (1973) were used to examine the pairwise genetic differentiation and gene flow, respectively, between the population clusters (IA, IB, and II) (Table 4). The highest level of genetic differentiation $\left(G_{\mathrm{ST}}=0.3109\right)$ was detected between Central America (II) and northern Amazon (IB) (Table 4). The estimates of gene flow $\left(N_{\mathrm{M}}\right)$ were moderate among South America populations and between Amazonian and southern South America and Central America. Only the gene flow estimate between Central America plus NW Colombia (II) and northern Amazon (IB) was below 1. Population comparisons with $N_{\mathrm{M}}$ values less than 1 are considered to have no gene flow (Nei, 1973, 1975).

Tajima's (1989) $D_{\mathrm{T}}$ and Fu and Li's (1993) $F$ and $D$ neutrality tests found that cluster I and IA have significant negative $D$ and $F$ values, and nonsignificant negative $D_{\mathrm{T}}$ values (Table 5). The results allow rejection of the neutral model in these regions, as a result of two possible factors: (1) a relatively recent population expansion, which can raise the number of low-frequency variants, and (2) natural selection. The neutral model is also rejected in cluster $\mathrm{IB}$, where the $D_{\mathrm{T}}, D$, and $F$ values were all significantly positive (cluster II also had positive values, but nonsignificant), which suggests possible balancing selection or population subdivision (Table 5).

Fu's $F_{S}$ test (1997) and Strobeck's $S$ statistic (1987) determined that both cluster I and IA have significantly negative $F_{\mathrm{S}}$ values and positive $S$ of 0.995 and 1.000 , respectively, indicating possible population expansion. $\mathrm{Fu}$ (1997) states that $F_{\mathrm{S}}$ is the most powerful test for detecting population expansion and genetic hitchhiking, followed by Tajima's $D_{\mathrm{T}}$, and Fu and Li's $D$ and $F$ tests (Fu and $\mathrm{Li}$, 1993). Cluster IB has significantly positive $F_{\mathrm{S}}$ and a low $S$ statistic of 0.0001 , indicating possible background selection. Cluster II also had a positive $F_{\mathrm{S}}$ and low $S$-value, but they were not statistically significant.

Through a graphical illustration of the mismatch distribution it is possible to determine if there is a smooth unimodal distribution following the Poisson 
Table 5 Summary statistics for polymorphisms of Anopheles darlingi

\begin{tabular}{|c|c|c|c|c|c|c|c|}
\hline & $V S$ & $r$ & $D_{T}$ & $D$ & $F$ & $S$ & $F_{S}$ \\
\hline $\begin{array}{l}\text { I. South America } \\
N=82\end{array}$ & 66 & 0.0174 & -1.089 & $-2.571^{*}$ & $-2.369^{*}$ & $0.9950^{*}$ & $-4.499^{*}$ \\
\hline $\begin{array}{l}\text { A. Amazonian and SSA } \\
N=58\end{array}$ & 62 & 0.0105 & -1.614 & $-2.801^{*}$ & $-2.813^{*}$ & $1.0000^{*}$ & $-8.421^{*}$ \\
\hline $\begin{array}{l}\text { B. Northern Amazon } \\
N=24\end{array}$ & 15 & 0.7395 & $2.921^{*}$ & $1.529^{*}$ & $2.275^{*}$ & $0.0001^{*}$ & $14.99^{*}$ \\
\hline $\begin{array}{l}\text { II. Central America } \\
N=26\end{array}$ & 15 & 0.2276 & 0.072 & 0.408 & 0.357 & 0.1700 & 2.568 \\
\hline
\end{tabular}

South America includes all of the localities in South America except Nec (Colombia). Northern Amazon includes Tar, Li, Ant, Trp (French Guiana). Amazonian and SSA (Southern South America) includes Tai, Bel, Ara, Peb, Moj, Cap, Dou, Pex, Itb, BV, IQ (Peru). Central America includes Ixa, Gol, Cay, Nec (Colombia). $N=$ number of sequences used; VS = number of variable sites; $r=$ raggedness statistic; $D_{\mathrm{T}}=$ Tajima's $\mathrm{D} ; D=\mathrm{Fu}$ and Li's $D$ test; $F=\mathrm{Fu}$ and Li's $F$ test; $S=$ Strobeck's $S$ statistic; $F_{\mathrm{S}}=\mathrm{Fu}^{\prime} \mathrm{s} F_{\mathrm{S}}$ statistic; ${ }^{*}$ shows a significant $P$-value.

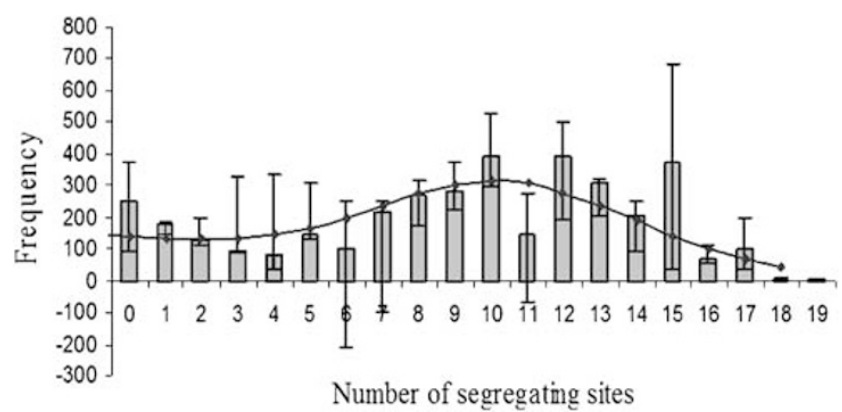

Figure 4 Mismatch distribution of all the localities in South America (cluster I). The bar graph is the observed mismatch distribution for South America. The line graph is the expected distribution of a recently expanded population. The error bars are $95 \%$ confidence interval estimates of the observed values.

distribution characteristic of a recent bottleneck or population expansion, or a multimodal distribution indicating a population at MDE. In contrast to the previous demographic history analyses for A. darlingi, the mismatch distribution did not demonstrate the expected unimodal distribution for all the localities together or for either primary or secondary clusters. The observed mismatch distribution for cluster I differed significantly from the simulated distribution of a demographic expansion model (Figure 4). The distribution for all the localities throughout Central and South America showed a multimodal distribution typical of populations at MDE.

The raggedness statistic for clusters I and IB are both very small (0.0174 and 0.0105 , respectively), suggesting a population expansion. Cluster IB has a large $r$-value (0.7395), indicating a population at equilibrium. Time since the population expansion can be estimated from $t=\tau / 2 \mu$, where $\mu$ is the mutation rate per site per generation (Slatkin and Hudson, 1991). The Drosophila mutation rate of $10^{-8} / \mathrm{site} /$ year (Powell et al, 1986) and 10 generations/year (Walton et al, 2000) were used in the calculation. The estimate of $\tau$, from the raggedness calculation, is 4.951 for cluster $\mathrm{I}$, and 3.176 for cluster IA. Therefore, the time to expansion for $A$. darlingi in South America is approximately 253119 years ago (95\% CI, 85554-402419), and in Amazonian and southern South America is approximately 162372 years ago (95\%
CI, 54 882-258144). Both expansion times are during the late Pleistocene.

The Mantel analysis to test the null hypothesis of the independence of the geographic and genetic distance between each population was conducted to test for isolation by distance. The correlation was not significant $\left(R^{2}=0.011, P=0.489\right)$.

\section{Discussion}

In a review of evolutionary studies Donnelly et al (2002) claim that the genetic population structure of primary malaria vectors is shallow with a weak effect of distance on differentiation, and this has been supported by studies of the major African vectors A. gambiae (Lehmann et al, 1996) and $A$. arabiensis (Donnelly and Townson, 2000). Our analyses detected considerable population structure, and isolation by distance was detected by Conn et al (1999) for A. darlingi in South America. A similar pattern was also found in neotropical vectors $A$. aquasalis (Fairley et al, 2002) and A. albimanus (De Merida et al, 1999), although in a more recent study in the latter species the effect of distance on differentiation was weak (Molina-Cruz et al, 2004).

In our study of $A$. darlingi, the inference of range expansion was well supported but isolation by distance was not. Isolation by distance and the low nucleotide diversity observed in Central American populations of A. albimanus and low nucleotide diversity in $A$. darling $i$ could be due to small effective migration rates and effective population size, and/or genetic drift (De Merida et al, 1999; Molina-Cruz et al, 2004). The nucleotide diversity estimates for $A$. gambiae are also low, which is consistent with a large panmictic population (Besansky et al, 1997; Lehmann et al, 1998). These differences may be due to lack of isolation by distance in the African Anopheles, as compared to the Neotropical Anopheles, and their high dispersal ability, large effective population size, and/or recent range expansion (corresponding to the human population expansion during the arrival of agriculture in West Africa) (Lounibos and Conn, 2000; Donnelly et al, 2001, 2002).

The $N_{\mathrm{M}}$ estimates between Central America and the northern Amazon indicated little or no recurrent gene flow $\left(N_{\mathrm{M}}<1\right)$. Contemporary gene flow estimates are important in malaria vectors because they are used to predict the spread of genes, essential information for 
effective introduction of transgenes for Plasmodium resistance (Cohuet et al, 2005; Tripet et al, 2005). No gene flow combined with high genetic differentiation may be the result of vicariance or obstruction by natural barriers (ie, topography or habitat that a migrating individual cannot cross) existing between Central America and northern Amazon. Anopheles albimanus data suggest that a single barrier exists within Central America, which may be the mountain range that crosses Costa Rica and Western Panama (Molina-Cruz et al, 2004). The phylogeographic break between Central American plus NW Colombia and South American A. darlingi is consistent with studies of other Neotropical taxa, such as Neotropical butterflies (Brower 1994), toads (Slade and Moritz, 1998), bats (Hoffmann and Baker, 2003) and trees (Dick et al, 2003). However, Manguin et al (1999) observed substantial gene flow among populations of $A$. darlingi throughout its geographic range using four nonmitochondrial markers (isozyme, RAPD-PCR, ITS2, and morphology). These conflicting results may be due to the differences in mitochondrial and nuclear DNA inheritance and evolutionary histories which can affect estimates of gene flow (Presa et al, 2002). Mitochondrial DNA evolves relatively rapidly, it is maternally inherited, and has an extremely low level of recombination as compared to the nuclear genome (Avise, 2000).

Manguin et al (1999) found that $A$. darlingi from Belize differed from all the South American populations by a three-base deletion in the rDNA ITS2 marker. There is no evidence of clinal variation, and the range of $A$. darlingi in Central America is narrow (Manguin et al, 1999). Therefore, Manguin et al (1999) suggested the differentiation is either due to a recent introduction event that may have been caused by humans, or an extrinsic factor. One interpretation of our data is a possible introduction event from Colombian $A$. darlingi populations into Central America. More ancestral and diverse haplotypes were observed in Amazonian and southern Brazil populations, so they are likely older, and Colombian haplotypes are, of the South American samples examined in this study, most closely related to the Central American haplotypes.

In general, older populations have a higher diversity than younger populations (Kambhampati and Rai, 1991; Molina-Cruz et al, 2004). In our study, the older populations with the highest diversity are ITB, CAP and PEX, and cluster IA (Amazonian and southern South America). According to Avise (2000), high haplotype diversity relative to the nucleotide diversity suggests a population bottleneck followed by a rapid population expansion and buildup of mutations; nearly all the populations (except TAI and PEB) of $A$. darling $i$ in cluster IA, and all the localities together fit this criterion.

We hypothesized that the Amazonian populations of $A$. darlingi had undergone a population expansion similar to A. marajoara in northern Brazil (Lehr, 2003), based on regional patterns determined for many organisms reviewed in Avise (2000). The large proportion of shared haplotypes and lack of unique haplotypes in the Amazon region in Brazil, and most of the demographic history analyses support an expansion in Amazonian and southern South America populations of A.darlingi. However, mismatch analysis shows a multimodal pattern characteristic of populations at MDE. Harpending (1994) states that a population expansion that is too recent, for example at the end of the Pleistocene epoch, would not result in a smooth unimodal mismatch distribution. MDE is thought to be achieved when the effective population $\left(N_{\mathrm{e}}\right)$ size has stayed constant for $2 N_{\mathrm{e}}-4 N_{\mathrm{e}}$ generations (Nei and Li, 1976). A. darlingi population size probably fluctuates due to its dependence on specific climatic and environmental conditions, which have changed dramatically over the last millennia (Prance, 1982; Absy et al, 1991; Cavalli-Sforza et al, 1994; Nicholson, 1995; Donnelly et al, 2001). The estimated expansion time for $A$. marajoara was much more recent (36400 years ago in the eastern Amazon; Lehr, 2003) as compared to $A$. darlingi (estimated time to expansion is $>100000$ years). This difference may reflect the cycles of Amazonian savannah contraction and re-expansion, and thus habitat availability owing to the differences in habitat preference between $A$. marajoara (breeding sites associated with savannah and agricultural habitat; Conn et al, 2002; Lehr, 2003) and A. darlingi (primary breeding sites along warm lowland rivers; Rozendaal, 1990; Roberts et al, 2002).

If $A$. darlingi, like other primary vectors (eg, A. gambiae) has only recently become a human pest, it would be expected to show a recent population expansion. However, the historical human population expansion in the Amazon region is predicted to have occurred between 10000 (Roosevelt et al, 1991) and 2500 years BP (Willis et al, 2004), and a rapid decline in indigenous human population size occurred after colonial contact in the 18th-19th centuries (Willis et al, 2004). Brazilian government settlement policies, still in effect today, have caused nonindigenous human populations in many areas of the Amazon in Brazil to expand significantly during the 20th century (Cruz Marques, 1987; Alecrim, 1992; Schmink and Wood, 1992). Our estimates support a very different history for $A$. darlingi in South America compared with A. gambiae in subSaharan Africa, despite both being primary vectors. Anopheles darlingi being a more opportunistic feeder (Charlwood, 1996) is not nearly as dependent on human blood meals compared with $A$. gambiae (White, 1974; Coluzzi et al, 1979; Besansky et al, 2004). Therefore its populations are more likely to fluctuate based on climatic conditions (that would influence breeding site availability) compared with $A$. gambiae's noteworthy dependence on human population densities (Coluzzi, 1982; Donnelly et al, 2001).

\section{Acknowledgements}

We are particularly grateful to Drs Robert H Gilman, Ranulfo González, John P Grieco, Sylvie Manguin, Marinete M Póvoa, Norma Padilla, and Richard C Wilkerson for providing samples. We thank members of the Conn laboratory for technical help and advice. We appreciate the comments of two anonymous reviewers who improved this manuscript. This study was funded by National Institutes of Health grants AI R2940116 and AI R0154139 to JEC.

\section{References}

Absy ML, Cleef AM, Fournier M, Martin L, Servant M, Sifeddine A et al (1991). Mise en évidence de quatre phases d'ouverture de la forèt dense dans le sud-est de l'Amazonie au cours des 60000 dernières anéés. Première comparison 
d'autres régions tropicales. CR Acad Sci Paris t.312 Série II: 673-678.

Alecrim WD (1992). Malaria, prospecting activities and government policies in the Amazon Region. Rev Inst Med Trop São Paulo 34: S48.

Aramburu Guarda J, Ramal Asayag C, Witzig R (1999). Malaria re-emergence in the Peruvian Amazon region. Emerg Infect Dis 5: 209-215.

Avise JC (2000). Phylogeography. The History and Formation of Species. University Press: Massachusetts.

Besansky NJ, Hill CA, Costantini C (2004). No accounting for taste: host preference in malaria vectors. Trends Parasitol 20: 249-251.

Besansky NJ, Lehmann JA, Fahey GT, Fontenille D, Braack LEO, Hawley WA, Collins FH (1997). Patterns of mitochondrial DNA variation within and between African malaria vectors, Anopheles gambiae and $A$. arabiensis, suggest extensive gene flow. Genetics 147: 1817-1828.

Brower AVZ (1994). Rapid morphological radiation and convergence among races of the butterfly Heliconius erato inferred from patterns of mitochondrial DNA evolution. PNAS USA 91: 6491-6495.

Castelloe J, Templeton AR (1994). Root probabilities for intraspecific gene trees under neutral coalescent theory. Mol Phyl Evol 3: 102-113.

Cavalli-Sforza LL, Menozzi P, Piazza A (1994). The History and Geography of Human Genes. Princeton University Press: New Jersey.

Charlwood JD (1996). Biological variation in Anopheles darlingi root. Mem Inst Oswaldo Cruz 91: 391-398.

Charlwood JD, Alecrim WA (1989). Capture-recapture studies with the South American malaria vector Anopheles darlingi Root. Ann Trop Med Parasitol 83: 569-576.

Clement M, Posada D, Crandall KA (2000). TCS: a computer program to estimate gene genealogies. Mol Ecol 9: 1657-1659.

Cohuet A, Dia I, Simard F, Raymond M, Rousset F, AntonioNkondjio C et al (2005). Gene flow between chromosomal forms of the malaria vector Anopheles funestus in Cameroon, Central Africa, and its relevance in malaria fighting. Genetics 169: 301-311.

Coluzzi M (1982). Spatial distribution of chromosomal inversions and speciation in anopheline mosquitoes. In: Bargozzi C (ed) Mechanisms of Speciation. Alan R Liss., Inc.: New York. pp 143-153.

Coluzzi M, Sabatini A, Petrarca V, Di Deco MA (1979). Chromosomal differentiation and adaptation to human environments in the Anopheles gambiae complex. Trans $R$ Soc Trop Med Hyg 73: 483-497.

Conn JE, Rosa-Freitas MG, Luz SLB, Momen H (1999). Molecular population genetics of the primary neotropical malaria vector Anopheles darlingi using mtDNA. J Am Mosq Control Assoc 15: 468-474.

Conn JE, Wilkerson RC, Segura NO, De Souza RTL, Schlichting CD, Wirtz RA, Povoa MM (2002). Emergence of a new neotropical malaria vector facilitated by human migration and changes in land use. Am J Trop Med Hyg 66: 18-22.

Crandall KA, Templeton AR (1993). Empirical tests of some predictions from coalescent theory with applications to intraspecific phylogeny reconstruction. Genetics 134: 959-969.

Cruz Marques A (1987). Human migration and the spread of malaria in Brazil. Parasit Today 3: 166-170.

De Merida AM, De Mata MP, Molina E, Porter CH, Black IV WC (1995). Variation in ribosomal DNA intergenic spacers among populations of Anopheles albimanus in South and Central America. Am J Trop Med Hyg 53: 469-477.

De Merida AM, Palmieri M, Yurrita M, Molina A, Molina E, Black IV WC (1999). Mitochondrial DNA variation among Anopheles albimanus populations. Am J Trop Med Hyg 6: $230-239$.

Deane LM (1947). Observaçoes sobre a malaria na Amazonia brasileira. Rev Soc Bras Med Trop 24: 13-20.
Deane LM (1988). Malaria studies and control in Brazil. Am J Trop Med Hyg 33: 223-230.

Deane LM, Causey OR, Deane MP (1946). An illustrated key by adult female characteristics for identification of thirty-five species of Anopheline from the northeast and Amazon regions of Brazil, with notes on the malaria vectors (Dipeta: Culicidae). Am J Trop Med 18: 1-18.

Dick CW, Abdul-Salim K, Bermingham E (2003). Molecular systematics reveals cryptic Tertiary diversification of a widespread tropical rainforest tree. Am Naturalist 162: 691-703.

Donnelly MJ, Licht MC, Lehmann T (2001). Evidence for recent population expansion in the evolutionary history of the malaria vectors Anopheles arabiensis and Anopheles gambiae. Mol Biol Evol 18: 1353-1364.

Donnelly MJ, Pinto J, Girod R, Besansky NJ, Lehmann T (2004). Revisiting the role of introgression vs shared ancestral polymorphisms as key processes shaping genetic diversity in the recently separated sibling species of the Anopheles gambiae complex. Heredity 92: 61-68.

Donnelly MJ, Simard Frédéric, Lehmann T (2002). Evolutionary studies of malaria vectors. Trends Parasitol 18: 75-80.

Donnelly MJ, Townson H (2000). Evidence for extensive genetic differentiation among populations of the malaria vector Anopheles arabiensis in eastern Africa. Insect Mol Biol 9: 357-367.

Fairley TL, Povoa MM, Conn JE (2002). Evaluation of the Amazon River delta as a barrier to gene flow for the regional malaria vector, Anopheles aquasalis (Diptera:Culicidae) in northeastern Brazil. I Med Entomol 39: 861-869.

Forattini OP (1962). Parte Geral, Diptera, Anophelini, Entomologica Medica, Vol 1. Faculdade de Higiene e Saúde Pública, Universidade de São Paulo: São Paulo, Brasil. pp 622.

Forattini OP, Kakitani I, Massad E, Marucci D (1993). Studies on mosquitoes (Diptera: Culicidae) and anthropic environment. 3-Survey of adult stages at the rice irrigation system and the emergence of Anopheles albitarsis in southeastern Brazil. Revista de Saude Publica 27: 313-325.

Foster WA, Walker ED (2002). Mosquitoes (Culicidae). In: Mullen G, Durden L (eds) Medical and Veterinary Entomology. Academic Press: New York. Chapter 12, pp 204-256.

Freitas-Sibajev MG, Conn J, Mitchell SE, Cockburn AF, Seawright JA, Momen H (1995). Mitochondiral DNA and morphological analyses of Anopheles darlingi populations from Brazil (Diptera: Culicidae). Mosq Syst 27: 79-99.

Fu YX (1997). Statistical tests of neutrality of mutations against population growth, hitchhiking and background selection. Genetics 147: 915-925.

Fu YX, Li WH (1993). Statistical tests of neutrality of mutations. Genetics 133: 693-709.

Harpending HC (1994). Signature of ancient population growth in a low-resolution mitochondrial DNA mismatch distribution. Hum Biol 66: 591-600.

Harpending HC, Sherry ST, Rogers AR, Stoneking M (1993). The genetic structure of ancient human populations. Curr Anthropol 34: 483-496.

Hoffmann FG, Baker RJ (2003). Comparative phylogeography of short-tailed bats (Carollia: Phyllostomidae). Mol Ecol 12: 3403-3414.

Kambhampati S, Rai KS (1991). Mitochondrial DNA variation within and among populations of the mosquito Aedes albopictus. Genome 34: 288-292.

Kimura M (1983). The Neutral Theory of Molecular Evolution. Cambridge University Press: Cambridge, England.

Kreutzer RD, Kitzmiller JB, Ferreira E (1972). Inversion polymorphism in the salivary gland chromosomes of Anopheles darlingi Root. Mosq News 32: 555-565.

Krzywinski J, Besansky NJ (2003). Molecular systematics of Anopheles: from subgenera to subpopulations. Annu Rev Entomol 48: 111-139. 
Kumar S, Tamura K, Jakobsen IB, Nei M (2001). MEGA2: molecular evolutionary genetics analysis software. Bioinformatics 17: 1244-1245.

Lehmann T, Hawley WA, Gerbert H, Collins FH (1998). The effective population size of Anopheles gambiae in Kenya: implications for population structure. Mol Biol Evol 15: 264-276.

Lehmann T, Hawley WA, Kamau L, Fontenille D, Simard F, Collins FH (1996). Genetic differentiation of Anopheles gambiae populations from East and west Africa: comparison of microsatellite and allozyme loci. Heredity 77: 192-200.

Lehr MA (2003). Phylogenetics and Phylogeography of a Neotropical Anopheline Cryptic Species Complex. MS Thesis, University of Vermont.

Lounibos LP, Conn JE (2000). Malaria vector heterogeneity in South America. Am Entomologist 46: 238-249.

Lourenço-de-Oliveira R, Guimarães AEG, Arie M, Fernandes da Silva T, Castro MG, Motta MA, Deane LM (1989). Anopheline species, some of their habits and relation to malaria in endemic areas of Rondonia State, Amazon region of Brazil. Mem Inst Oswaldo Cruz 84: 501-514.

Lunt DH, Zhang DX, Szymura JM, Hewitt GM (1996). The insect cytochrome oxidase I gene: evolutionary patterns and conserved primers for phylogenetic studies. Insect Mol Biol 5: 153-165.

Maddison WP, Maddison DR (1997). MacClade: Analysis of Phylogeny and Character Evolution Version 3.07. Sinauer Associates: Massachusetts.

Malafronte RS, Marrelli MT, Marinotti O (1999). Analysis of ITS2 DNA sequences from Brazilian Anopheles darlingi (Diptera: Culicidae). J Med Entomol 36: 631-634.

Manguin S, Roberts DR, Peyton EL, Fernandez-Salas I, Barreto M, Fernandez Loayza R et al (1995). Biochemical systematics and population genetic structure of Anopheles pseudopunctipennis, vector of malaria in Central and South America. Am J Trop Med Hyg 53: 362-377.

Manguin S, Wilkerson RC, Conn JE, Rubio-Palis Y, Donoff-Burg JA, Roberts DR (1999). Population structure of the primary malaria vector in South America, Anopheles darlingi, using isozyme, random amplified polymorphic DNA, internal transcribed spacer 2, and morphologic markers. Am J Trop Med Hyg 60: 364-376.

Mantel N (1967). The detection of disease clustering and a generalized regression approach. Cancer Res 27: 209-220.

Mau B, Newton M (1997). Phylogenetic inference for binary data on dendrograms using Markov chain Monte Carlo. J Comput Graph Stat 6: 122-131.

Mau B, Newton M, Larget B (1999). Bayesian phylogenetic inference via Markov chain Monte Carlo methods. Biometrics 55: $1-12$.

Molina-Cruz A, de Merida AM, Mills K, Rodriguez F, Schoua C, Yurrita MM et al (2004). Gene flow among Anopheles albimanus populations in Central America, South America, and the Caribbean assessed by microsatellites and mitochondrial DNA. Am J Trop Med Hyg 71: 350-359.

Nei M (1973). Analysis of gene diversity in subdivided populations. Proc Natl Acad Sci USA 70: 3321-3323.

Nei M (1975). Molecular Population Genetics and Evolution, Vol 40. North Holland Publishing Company: North-Holland.

Nei M, Li WH (1976). The transient distribution of allele frequencies under mutation pressure. Genet Res 28: 205-214.

Nicholson SE (1995). Environmental change within the historical period. In: Goudie AS, Adams WM, Orme A (eds) The Physical Geography of Africa. Oxford University Press: Oxford, England. pp 60-75.

Pan American Health Organization (2002). Status of Malaria Programs in the Americas, CSP26/INF/3. Pan American Health Organization, Washington, DC.

Posada D, Crandall KA, Templeton AR (2000). GeoDis: a program for the cladistic nested analysis of the geographical distribution of genetic haplotypes. Mol Ecol 9: 487-488.
Póvoa MM, Conn JE, Schlichting CD, Amaral JC, Segura MN, Da Silva AN et al (2003). Malaria vectors, epidemiology, and the re-emergence of Anopheles darlingi in Belém, Pará, Brazil. J Med Entomol 40: 379-386.

Powell JR, Caccone A, Amato GD, Yoon C (1986). Rate of nucleotide substitution in Drosophila mitochondrial DNA and nuclear DNA are similar. Proc Natl Acad Sci USA 83: 9090-9093.

Prance GT (1982). A review of the phylogeographic evidences for Pleistocene climate changes in the Neotropics. Ann Mo Bot Gard 69: 594-624.

Presa P, Pardo BG, Martínez P, Bernatchez L (2002). Phylogeographic congruence between mtDNA and rDNA ITS markers in Brown Trout. Mol Biol Evol 9: 2161-2175.

Rannala B, Yang Z (1996). Probability distribution of molecular evolutionary trees: a new method of phylogenetic inference. J Mol Evol 43: 304-311.

Roberts DR, Manguin S, Rejmankova E, Andre R, Harbach RE, Vanzie E et al (2002). Spatial distribution of adult Anopheles darlingi and Anopheles albimanus in relation to riparian habitats in Belize, Central America. J Vector Ecol 27: 21-30.

Rogers AR (1995). Genetic evidence for a pleistocene population explosion. Evolution 49: 608-615.

Rogers AR, Harpending H (1992). Population growth makes waves in the distribution of pairwise differences. Mol Biol Evol 9: 552-569.

Roosevelt AC, Housley RA, Imazio da Silveira M, Maranca S, Johnson R (1991). Eighth millennium pottery from a prehistoric shell midden in the Brazilian Amazon. Science 254: 1621-1624.

Rozas J, Rozas R (1999). DnaSP version 3: an integrated program for molecular population genetics and molecular evolution analysis. Bioinformatics 15: 174-175.

Rozendaal JA (1990). Observations on the distribution of anophelines in Suriname with particular reference to the malaria vector Anopheles darlingi. Mem Inst Oswaldo Cruz 85: 221-234.

Sallum MAS, Schultz, TR, Wilkerson RC (2000). Phylogeny of Anophelinae (Diptera Culicidae) based on morphological characters. Ann Entomol Soc Am 93: 745-775.

Schmink M, Wood CH (1992). Contested Frontiers in Amazonia. Columbia University Press: New York.

Schneider S, Roessli D, Excoffier L (2000). Arlequin: A Software for Population Genetic Data. Genetics and Biometry Laboratory, University of Geneva: Switzerland.

Schoeler GB, Flores-Mendoza C, Fernandez R, Davila JR, Zyzak M (2003). Geographical distribution of Anopheles darlingi in the Amazon Basin region of Peru. J Am Mosq Control Assoc 19: 286-296.

Slade RW, Moritz C (1998). Phylogeography of Bufo marinus from its natural and introduced ranges. Proc $R$ Soc Lond Ser B - Biological Sciences 265: 769-777.

Slatkin M, Hudson RR (1991). Pairwise comparisons of mitochondrial DNA sequences in stable and exponentially growing populations. Genetics 129: 555-562.

Soares Gil LH, Alves FP, Zieler H, Salcedo JMV, Durlacher RR, Cunha RPA et al (2003). Seasonal malaria transmission and variation of anopheline density in two distinct endemic areas in Brazilian Amazônia. J Med Entomol 40: 636-641.

Strobeck C (1987). Average number of nucleotide differences in a sample from a single subpopulation: a test for population subdivision. Genetics 117: 149-153.

Swofford DL (2003). PAUP (Phylogenetic Analysis Using Parsimony) and Other Methods, Version 4. Sinauer Associates: Massachusetts.

Tajima F (1989). Statistical method for testing the neutral mutation hypothesis by DNA polymorphisms. Genetics 123: 585-595.

Tripet F, Dolo G, Lanzaro GC (2005). Multilevel analyses of genetic differentiation in Anopheles gambiae s.s. reveal 
patterns of gene flow important for malaria-fighting mosquito projects. Genetics 169: 313-324.

Walton C, Handley JM, Tun-Lin W, Collins FH, Harbach RE, Baimai $\mathrm{V}$ et al (2000). Population structure and population history of Anopheles dirus mosquitoes in Southeast Asia. Mol Biol Evol 17: 962-974.

White GB (1974). Anopheles gambiae complex and disease transmission in Africa. Trans $R$ Soc Trop Med Hyg 68: 278-301.
WHO/TDR (2004). Disease Watch: Malaria. World Health Organization: Geneva.

Willis KJ, Gillson L, Brncic TM (2004). How 'virgin' is virgin rainforest? Science 304: 402-403.

Wright S (1951). The genetical structure of populations. Ann Eugenics 15: 323-354.

Zimmerman RH, Voorham J (1997). The use of impregnated bed nets and other materials for the control of malaria in the Americas. Pan Am J Public Health 2: 18-25. 